\title{
$50 \mathrm{Wh}$ 급 배터리 충전을 위한 휴대용 자가발전시스템 연구
}

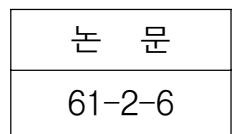

\section{A Study of a Manual Generator System for 50Wh Battery Charge}

\author{
이 지 영 ${ }^{*}$ 구 대 현* 한 충 규** \\ $(\mathrm{Ji}$-Young Lee $\cdot$ Dae-Hyun Koo $\cdot$ Choong-Kyu Han)
}

\begin{abstract}
This paper deals with an design of axial flux electric machine which is a key element for a compact size in a portable and manual generator system. It is expected that the generator system with an axial flux electric machine is more light and has higher efficiency than other types of generator systems. And it is used the soft magnetic composite core instead of silicon steel core in the axial flux electric machine for more compact size. The weight and efficiency of the generator system are the main keys to select the value of design variables. In this paper, the overall design process to meet the design goals, and the design results are presented with experiment results.
\end{abstract}

Key Words : Axial flux machine, Electric machine, Generator, Soft magnetic composite

\section{1. 서 론}

최근의 군사 전을 정보전, 네트워크 중심 전, 무인화/로봇 전 등과 같이 명명하는데서 알 수 있듯이, 전장 환경에서 전 원공급을 필요로 하는 장비가 증가하는 추이를 나타내고 있 다[1],[2]. 군의 이동식 전자장비의 일반적인 전원 공급 수단 은 배터리로서, 일반적으로 전자장비 하나당 기본 배터리와 함께 여분의 수개의 배터리가 필요하다. 전자장비의 개수가 증가할수록 여분의 배터리 개수 또한 증가하여 이동시 큰 부하가 된다. 또한 배터리가 모두 방전되거나 여분이 부족 한 상태에서 긴급 상황을 맞게 되면 적은 충전전력으로라도 전원을 공급받아 네트워킹이 이루어지거나 전원장비를 사 용할 수 있어야 군의 안전성을 유지할 수 있다. 따라서 여 분의 배터리 운반개수를 감소시킴으로서 군의 민첩성을 향 상시키고, 비상시 자가 발전이 가능하게 함으로서 군의 전자 장비 운용의 안정성을 향상시키기 위해 자가발전시스템이 필요하다[3].

자가 발전 시스템 중 사람의 손과 발을 이용하여 전동기 를 돌려 발전을 하는 기술은 이미 1970년대부터 미국군에 의해서 개발되어 왔다. 초기에는 $\mathrm{DC}$ 전동기를 이용했으나 잘 활용되지 못하고, 영구자석형 $\mathrm{AC}$ 전동기를 사용함으로서 출 력밀도와 효율을 높이는 방향으로 개발되어 왔다. 영구자석 재료가 페라이트와 사마륨 코발트에서 네오디움계로 바뀌면 서 발전기 자체의 효율은 더 높아졌으나, 발전 전압의 크기

† 교신저자, 정회원 : 한국전기연구원 선임연구원

E-mail : jylee@keri.re.kr

* 정 회 원 : 한국전기연구원 책임연구원

** 비 회 원 : 국방과학연구소 선임연구원

접수일자 : 2011년 11월 9일

최종완료 : 2011년 12월 15일
와 정류기 성능에 따라 정류기에서 열이 발생하여 시스템 효율은 오히려 더 저감되기도 하였다. 따라서 용량을 확보 하면서 출력밀도와 효율이 높은 자가발전 시스템을 개발하 기위해서는 발전시스템을 구성하는 주요 구성품 각각에 대 한 이해와 이를 바탕으로 한 발전기 설계가 이루어져야 한 다 [4]-[5].

본 논문에서는 휴대가 간편하고 손으로 구동하는 발전 시 스템 개발을 위해 연구한 내용을 소개하고자 한다. '기어-발 전기-정류기-충전기’로 구성되는 발전시스템에서, 휴대가 간 편하도록 부피와 무게를 줄이기위해 발전시스템을 소형, 경 량화하고 출력밀도를 높이는 데 중점을 두었다. 본문에서는 발전 시스템의 무게당 출력을 증가시키는 데 핵심인 기어와 발전기 설계에 대해 보다 집중적인 설명이 이루어진다. 배 터리와 정류기-충전기 특성을 반영하여 기어와 발전기 각각 의 사양을 결정하고 기본설계를 시작하여 상세설계와 특성 해석 그리고 실험에 이르기까지의 전반적인 설계와 검토 과 정을 다룬다.

\section{2. 본 론}

\section{1 자가 발전 시스템 설계}

\subsection{1 발전기 시스템 구성과 입출력 관계}

본 논문에서 개발하고자 하는 자가발전 시스템의 구성과 입출력 관계는 그림 1 과 같다. 한 사람이 한 손으로 전달 할 수 있는 최대 힘은 회전(turning)으로 $28 \mathrm{~W}$ 정도가 되고, pedaling 형식으로 양손으로 회전력을 발생시키면 최대 $50 \mathrm{~W}$ 를 넘길 수 있다. 평균 성인이 손으로 구동해서 얻을 수 있는 최대 용량은 35 65W 정도로 알려져 있다[7]-[8]. 


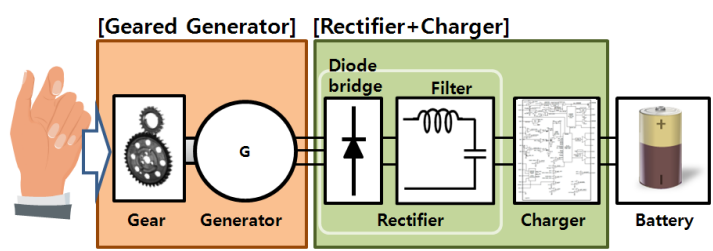

그림 1 자가발전 시스템 구성과 입출력 관계도

Fig. 1 Generating system components

발전기 시스템은 '기어-발전기-정류기-충전기'의 네 부분 으로 분류될 수 있는데, 그 각각은 사람의 동력을 직접 전달 하기위한 크랭크의 연장 선 상에서 속도를 가변시키는 기어, 기계적인 힘을 전기적인 힘으로 변환시키는 발전기, 그리고 교류전원을 직류전원으로 바꾸어 배터리를 충전시키는 정류 기와 충전기이다. 발전 시스템의 효율이 $80 \%$ 이상이 되면, $65 \mathrm{~W}$ 의 입력으로 $50 \mathrm{Wh}$ 급 배터리 충전이 가능하다.

발전기 시스템의 부하가 되는 배터리는 무게 당 용량이 가장 크고 성능이 우수하여 현재의 군장비 전지로 보급 확 산되고 있는 리튬이온폴리머 전지를 고려하였다. 배터리 전 류용량은 $3 \mathrm{Ah}$ 이고, 전압은 4 개 셀을 직렬로 연결하여 $16.8 \mathrm{~V}$ 인 50Wh급 배터리를 구성하였다.

\subsection{2 증속비 및 발전기 사양 결정}

일반적으로 속도가 높아질수록 같은 용량에 대해 전동기 또는 발전기의 부피와 무게는 감소하고, 기어는 기어 증속비 가 증가하므로 부피나 무게가 증가하게 된다. 따라서 먼저 증속 비 변화에 따른 무게 및 특성 변화를 분석하여 기어 증속비와 발전기의 정격 속도를 결정하였다.

자가발전 시스템 설계 사양에서는 기어 증속 비를 다섯 가지 경우에 대해 검토하였다. 증속 비가 $1: 10,1: 20$, 그리고 $1: 30$ 일 때는 3 개의 스퍼기어를 사용하고, $1: 40$ 과 $1: 50$ 에는 4 개의 기어를 조합하여 원하는 증속 비를 구성하였다. 기어 구조의 안정성을 위해 2 개 기어 조합에 의한 증속 비는 10 을 넘지 않도록 하였다. 예로서 $1: 10$ 인 경우에는 기어 증속 비가 60:12와 24:12의 비로 결정되도록 하였고, $1: 50$ 인 경우 에는 증속 비가 60:12와 50:10, 그리고 $24: 12$ 의 비 조합으로 결정되도록 하였다. 기어박스 너비는 발전기 너비보다 작은 직경 $70 \mathrm{~mm}$ 이내로 설계하였다.

자가발전 시스템에 크랭크로부터 입력되는 정격 속도가 $100 \mathrm{rpm}$ 일 때, 각각의 증속 비에 의해 결정되는 발전기의 정 격 속도 변화는 $1000 \mathrm{rpm}$ 에서 $5000 \mathrm{rpm}$ 이 된다. 증속 비에 의해 결정되는 각각의 속도에서 출력 $60 \mathrm{~W}$, 선간 전압 $20 \mathrm{~V}$, 그리고 효율 $90 \%$ 를 만족하도록 임의로 결정된 10 극 12 슬롯 에서 고정자 치 두께와 턴수, 그리고 최 외경만을 변화시켜 효율과 무게 변화를 확인하였다. 자연 냉각 조건을 고려하 여 전류밀도는 $4 \mathrm{~A} / \mathrm{mm}^{2}$ 이하가 되고, 철심의 자속밀도는 가 장 포화가 심한 고정자 치 부분에서 $1.8 \mathrm{~T}$ 를 넘지 않도록 하 였다. 이러한 조건에서 가장 효율이 좋고 가벼운 모델을 각 증속 비에서 최적화된 것으로 결정하였다.

기어 증속 비 증가, 즉 속도 증가에 따라 동일한 출력에 서 기어는 기어와 기어 치 개수의 증가로 무게가 증가하게 되고, 발전기는 발생 전압이 권선의 직렬 턴수와 주파수에
비례하므로 속도가 높아져 주파수가 증가할 수록 턴수를 줄 일 수 있으므로 전체 부피와 무게가 줄어들게 된다. 그러나 속도 증가에 따라 줄어드는 양상은 그림 2에 보는 바와 같 이 비선형적이다. 발전기 무게에 비해 기어 무게는 무시할 수 있을 정도로 작고, 증속 비가 1:20 이상에서 발전기의 무 게 변화는 크지 않은 것을 알 수 있다. 또한 다섯 가지 각 각의 증속비에서 수동입력에 따른 속도변화로 인해 출력전 압이 비례적으로 달라지는 경우, 전류밀도와 효율 특성은 그 림 3 과 그림 4 와 같다. 속도가 변해도 전류밀도는 크게 변 하지 않고, 모두 자연 냉각 조건 범위 내에 있다. 그러나 효 율은 큰 차이를 보이고 있다. 증속 비가 $1: 20$ 까지는 속도가 변해도 발전기의 효율이 $90 \%$ 부근이나 1:30부터는 속도 변 화에 따라 효율이 $85 \%, 1: 50$ 에서는 $80 \%$ 정도까지 감소하는 것을 볼 수 있다. 이는 기어 증속 비가 증가함에 따라 정격 운전 점의 속도 또한 증가하여 동일 출력 조건 하에서 부하 전류에 의한 동손은 감소하였는데 비해 주파수 증가에 따른 철손이 크게 증가하였기 때문이다. 결국 증속 비 변화에 따 른 기어와 발전기의 무게, 발전기의 전류밀도와 효율 특성을 분석한 결과 개발하고자 하는 발전시스템에서 가장 적절한 기어 증속 비는 1:20이라는 결론을 얻었다.

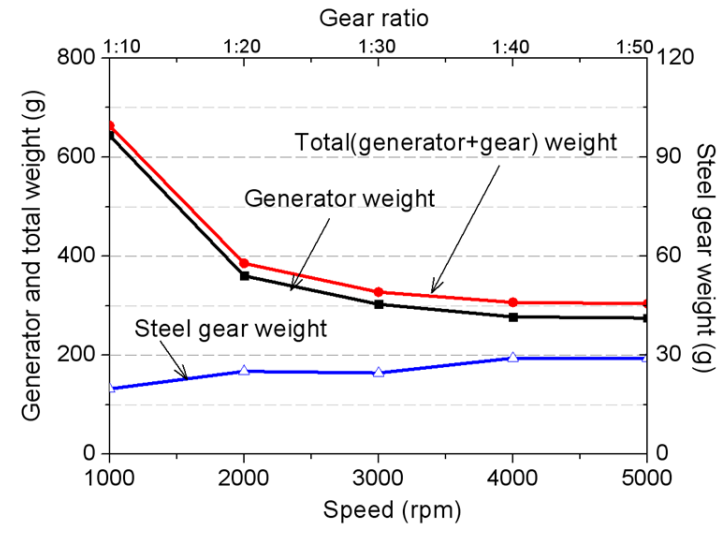

그림 2 증속 비 변화에 따른 발전기와 기어 무게변화

Fig. 2 Variation of generator and gear weight with gear ratio

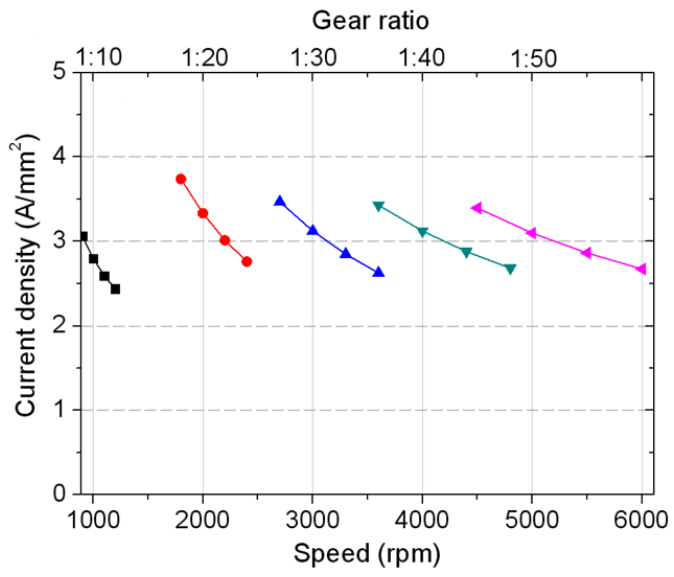

그림 3 각 증속비에서 속도 변화에 따른 전류밀도 변화

Fig. 3 Variation of current density with speed for each gear ratio 


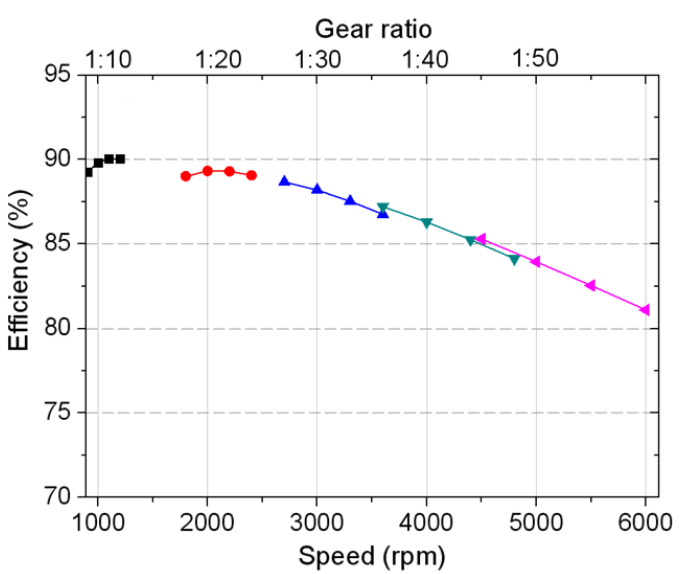

그림 4 각 증속비에서 속도 변화에 따른 효율 변화

Fig. 4 Variation of efficiency with speed for each gear ratio

표 1은 자가발전 시스템의 입출력 특성을 고려하여 자가 발전 시스템 각 구성품의 설계 사양 및 목표를 정리한 것이 다. 발전시스템을 구성하는 네 개 구성품은 서로 유기적이 므로, 발전기 설계를 위한 사양은 입, 출력 조건에 해당하는 나머지 구성품 사양에 의해 결정된다. 먼저 배터리 사양이 정해지면, 배터리 타입에 맞는 충전기 출력 특성이 결정된 다. 그리고 충전 성능을 향상시키기 위한 충전기 입력특성 을 결정하게 되면 그것이 정류기의 출력 특성이 된다. 발전 기는 이 정류기와 기 결정된 기어비에 의해서 설계 사양이 결정된다.

표 1 발전기 시스템 설계 사양

Table 1 Design specifications for a generating system

\begin{tabular}{|c|c|c|c|}
\hline \multicolumn{2}{|r|}{ 분류 } & 단위 & 값 \\
\hline \multirow[t]{2}{*}{ 수동입력 } & 속도 & $\mathrm{rpm}$ & $\begin{array}{c}85 \sim 110, \\
\text { 기준=정 격 }=100\end{array}$ \\
\hline & 파워 & $\mathrm{W}$ & 65 \\
\hline 기어 & 증속비 & - & $1: 20$ \\
\hline \multirow{4}{*}{ 발전기 } & 정격속도 & $\mathrm{rpm}$ & 2000 \\
\hline & 선간전압(실효값) & $\mathrm{V}$ & 16.7 (23.6Vpk) \\
\hline & 상전류(실효값) & A & 2.0 \\
\hline & 무게 & $\mathrm{kg}$ & 3 이하 \\
\hline \multirow{5}{*}{ 정류기 } & 타입 & \multicolumn{2}{|c|}{ Full-wave rectifier } \\
\hline & 다이오드 & \multicolumn{2}{|c|}{ Schottky diode } \\
\hline & 출력전압(평균) & $\mathrm{V}$ & 20.8 \\
\hline & 파워 & $\mathrm{W}$ & 51.5 \\
\hline & 효율 & $\%$ & 93 \\
\hline \multirow{4}{*}{ 충전기 } & 타입 & \multicolumn{2}{|c|}{$\begin{array}{c}\text { Synchronous Buck } \\
\text { Converter }\end{array}$} \\
\hline & 출력전압(평균) & $\mathrm{V}$ & 16.8 \\
\hline & 출력전류(평균) & A & 3.0 \\
\hline & 파워 & $\mathrm{W}$ & 50 (가변가능) \\
\hline 배터리 & 타입 & \multicolumn{2}{|c|}{$\begin{array}{c}\text { 4-Cell Lithium-Ion } \\
\text { Polymer }\end{array}$} \\
\hline
\end{tabular}

\subsection{3 발전기 설계}

결정된 시스템 사양에 따라 발전기 설계를 위한 설계 과 정은 다음과 같이 진행되었다. 시스템에 적합한 발전기 타 입을 결정하는 과정에서 설계 조건을 보다 구체적으로 정리 한다. 그리고 형상 변수로서 가장 큰 영향을 미치는 극수와 슬롯수 변화에 따른 특성을 분석하여 발전기의 기본적인 출 력특성을 만족하는 기본 형상을 결정하고, 이후 효율증가나 역기전력 고조파율(THD)을 줄이기위해 상세 설계에 들어가 게 된다. 기본형상을 결정하기 전 까지 수많은 경우의 수에 대한 검토가 이루어져야 하므로 해석 시간을 단축하기위해 이차원 등가자기회로법을 이용하였고, 상세 설계에서부터는 3차원 유한 요소 해석 (3-dimensional finite element analysis, 3D-FEA)을 수행하였다.

\section{가. 발전기 타입 결정 및 추가 설계 사양}

축방향 자속 발전기 (Axial Flux Generator, $\mathrm{AFG}$ ) 타입 은 평판구조로 인해 시스템 공간의 효율적 배치가 가능하므 로, 소형 경량화를 위한 자가발전 시스템에 적합하다. $\mathrm{AFG}$ 는 구성되는 회전자와 고정자 조합을 $1: 1,1: 2,2: 1,2: 3$ 등 다양하게 축방향으로 구성할 수 있으나, 발전시스템을 보다 소형화 하기위해 $\mathrm{AFG}$ 를 선택하였으므로 $\mathrm{AFG}$ 구조 중에서 도 가장 축방향으로 작아질 수 있는 $1: 1$ 구조 즉, Single-rotor/Single-stator 타입을 고려하였다. AFG 타입 으로 결정함에 따라 추가된 설계 사양은 코어이다. 출력밀 도를 보다 높이기위해서 고정자와 회전자에 연자성분말(soft magnetic composite, $\mathrm{SMC}$ )코어를 사용하였다. SMC 코어는 철심분말을 금형으로 찍어내어 구성하므로 규소강판을 적층 하여 제작하는 것보다 공간 배치의 효용성을 고려한 3 차원 구조로 설계가 가능한 이점이 있다. 그러나 현재 $\mathrm{SMC}$ 재질 에 대해 가장 독보적으로 개발되어 있는 회그네스사의 소말 로이 시리즈를 이용한 코어의 강도가 철의 $1 / 3 \sim 1 / 10$ 정도 밖에 되지 않으므로, 강도 유지를 위해 확보해야하는 최소두 께가 설계과정에 고려되어야 하며, 이는 $\mathrm{SMC}$ 코어 소결기 술을 가진 제작자의 경험적 요인을 바탕으로 하는 경우가 많다. 표 2는 본 연구에서 고려한 $\mathrm{SMC}$ 코어의 최소 두께로 서, 특성해석 과정에서 코어의 자속밀도가 $1.8 \mathrm{~T}$ 를 넘지 않 으면 이 최소 치수를 유지하였다.

표 $2 \mathrm{SMC}$ 코어 설계 시 고려하는 최소 치수

Table 2 Minimum dimensions of SMC cores

\begin{tabular}{||c||c|c||}
\hline \hline 두께 제한 부위 & 최소두께 & 조건 \\
\hline \hline 요크 & $3.5 \mathrm{~mm}$ & 직경 $90 \mathrm{~mm}$ \\
\hline 치단부 (tooth tip) & $3.5 \mathrm{~mm}$ & - \\
\hline 치 모서리 라운드 & $1^{\sim} 2 \mathrm{~mm}$ & 가능한 크게 \\
\hline
\end{tabular}

\section{나. 극수, 슬롯수 결정}

결정된 설계 사양을 바탕으로, 출력 특성에 가장 크게 영 향을 미치는 설계 변수인 극수와 슬롯수 조합에 따른 특성 변화를 분석하였다. 제작성을 고려하여 극수는 24 극 이하, 슬롯 수는 18 슬롯 이하에서 집중권 권선이 가능한 극수와 슬롯 수 조합을 모두 검토하였다. 자기회로 직경이 $81 \mathrm{~mm}$, 
높이가 $20 \mathrm{~mm}$ 로 일정한 부피 내에서 고정자 치 너비와 턴 수만을 변화시켜 각 극수/슬롯수 조합 모델에서 효율이 가 장 좋은 점을 찾은 뒤, 증속 비 결정시 발전기 설계에서 제 약조건으로 가정한 전류밀도와 자속밀도를 만족하는 6 개 모 델을 선택하였다.

극수와 슬롯수의 최소공배수를 LCM이라 할 때, 6 개 모델 을 선택하기 전, 모든 경우의 수에 대해 검토한 결과를 본 [3]에서는 $\mathrm{LCM}$ 이 증가 할 수록 전류밀도와 전체 무게, 코깅 토크와 $\mathrm{THD}$ 는 감소하고 효율과 역률은 증가하는 대체적인 경향이 있었다. 그러나 그 중에 선택된 6 개 모델만의 분포는 경향성이 없고, 무게가 가벼우면 전류밀도가 높아지는 등 모 든 조건을 동시에 만족시키는 모델이 없다. 따라서 6 개 중 가장 특성이 좋은 모델을 선택하기위해, 전류밀도, 전체 무 게, 코깅토크와 THD (total harmonic distortion)는 작을수록 좋으므로 함께 분자에 두고, 효율과 역률은 값이 클수록 좋 으므로 함께 분모에 둔 값을 계산하였다. 각 파라미터의 절 대값 범위가 다양하므로 주요하게 고려되는 파라미터이면서 도 값 자체가 작은 $\mathrm{THD}$ 와 코깅토크, 그리고 전류밀도값에 가중치를 두어 식(1)과 같이 계산하였다. 그리고 각 모델의 점수분포를 본 것이 그림 5이다. 점수는 낮을수록 특성이 좋 은 것이므로 10 극 12 슬롯, 14 극 18 슬롯, 16 극 18 슬롯이 서로 비슷한 값을 가지면서 가장 좋은 모델로 결정되었다. 이 중 16 극 18 슬롯 모델에 대해 3D-FEA를 진행하였다.

$$
F(\text { score })=\frac{[f(W T)+f(T H D) \times 5+f(\operatorname{Cog} T) \times 5+f(C D) \times 10]}{[f(E F F)+f(P F)]}
$$

\section{2 자가 발전기의 유한요소 해석 결과}

\subsubsection{3차원 유한요소 해석 과정}

16 극 18 슬롯 모델에 대한 3D-FEA는 상용프로그램인 맥 스웰 $3 \mathrm{D}$ 를 이용하였다. $\mathrm{FEA}$ 에 의한 자계 해석 과정을 크게 Pre-process, Solving-process, Post-process의 3개 단계로 나눌 때, 각 단계를 다음과 같이 진행하였다.

먼저 Pre-process에서는 자계 해석에 필요한 모델링을 하 고 해석에 필요한 재질 정수 및 해석 조건을 입력하게 된 다. 다음의 5가지는 Pre-process 과정에 입력된 사항들이다.

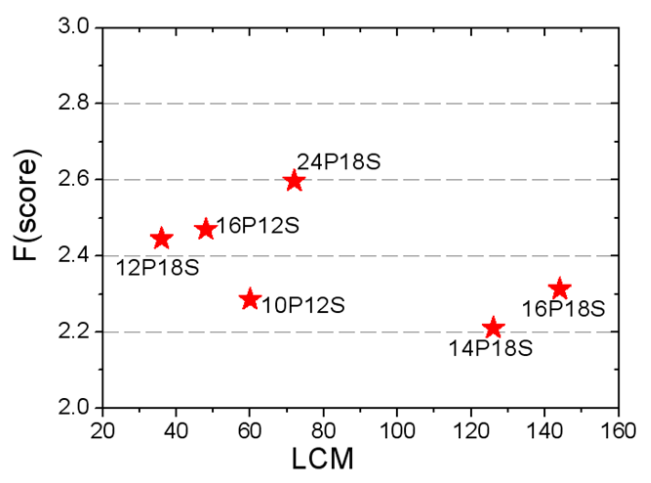

그림 5 6개 모델에 대한 점수

Fig. 5 Scores of 6 models
1) 3 차원 해석 모델 : 자기적 특성의 주기성을 고려했을 때 16 극 18 슬롯은 최소단위가 $1 / 2$ 모델이다. 따라서 그림 6 (a)와 같이 3 차원 모델링을 수행하였다. 자계해석을 위해 불필요한 구조물은 생략하고 자기회로에 영향을 주는 요소 만으로 단순화 하였다. 권선배치는 그림 7 과 같다.

2) 회전 운동 조건 : 정격속도 $100 \mathrm{rpm}$ 으로 수동 파워 입 력 시, 기어 증속 비에 의해 발전기 속도는 20 배 증속되므로 회전운동 속도는 2000rpm으로 입력하였다.

3) 경계 조건 : 짝수 개 영구자석이 모델링 되었고, 경계 에서 자속의 흐름 방향이 연속적이므로 (한 평면에서 나가 면, 다른 평면에서는 들어오는 방향), 온주기 경계조건 (full-periodic condition)을 부여하였다.

4) 외부회로 조건 : 발전기 모델로 해석을 수행하기 위하 여 외부 회로를 구성하였다. 그림 8에 3가지 단계를 나타내 었는데, 개방회로에 대한 해석은 발전기가 무부하 기자력을 얼마나 발생 시킬 수 있는가에 대한 평가이고, 저항회로에 대한 해석은 전력변환기를 부착하지 않은 상태에서 가장 간 단하게 발전기를 테스트해볼 수 있는 저항 부하에 대한 해 석이다. 마지막으로 정류회로에 대한 해석은 전력변환기를 고려한 회로 해석이다. 복잡한 충전기회로는 생략되었지만 충전기의 효율이 높으므로 이 해석결과를 통해서 실제 실험 에서 얻어지는 발전시스템의 출력과 큰 차이가 발생하지 않 을 것이라는 것을 유추 할 수 있다.

5) 재질정수 : 제작에 사용되는 재료를 고려하였다. 권선 은 구리, 영구자석은 $\mathrm{Nd}$ 희토류자석 계열의 $\mathrm{N} 38 \mathrm{SH}$, 회전자 와 고정자 코어는 모두 $\mathrm{SMC}$ 로 호그네스사 제품인 somaloy700-1P에 대한 특성을 입력하였다.

Solving-process 과정에서는 이상의 조건들을 바탕으로, 요소 분할 뒤 자계 해석을 수행하게 된다. 해석 모델은 그 림 6(b)와 같이 47만개 사면체 요소로 분할되었다. Post-process 과정에서는 해석 결과를 정리하고 판단한다. 그림 6(c)의 자속밀도 분포도 그 중에 한 예로서, 자속밀도 분포를 통해, 해석이 바르게 되었는지, 심한 국부 포화가 일 어났는지 등을 판단할 수 있다. 설계결과가 사양을 만족하 지 못하면, 고정자 치와 영구자석 형상 등 세부 치수를 조정 한다. 해석결과는 3 가지 외부회로에 따라 정리하였다.

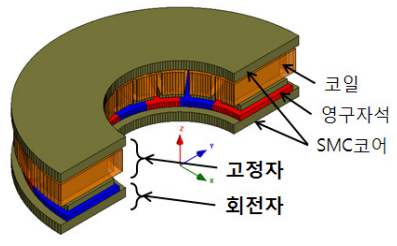

(a) 해석모델 ( $1 / 2$ 모델)

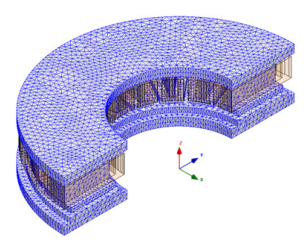

(b) 요소 분할도

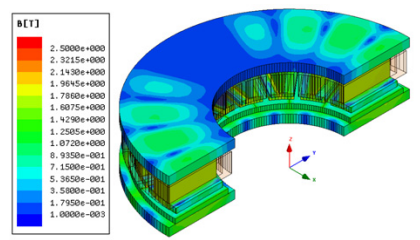

(c) 자속밀도 분포도

그림 6 3D FEA 해석모델과 자속밀도 분포

Fig. 6 3D FEA model and magnetic flux density distribution 


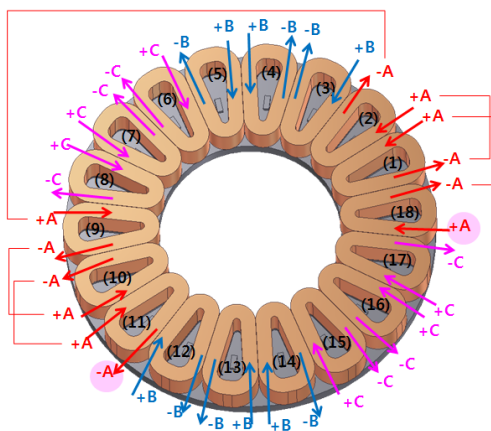

그림 7 16극 18슬롯 모델의 권선 배치도

Fig. 7 A drawing of 16-pole 18-slot model winding

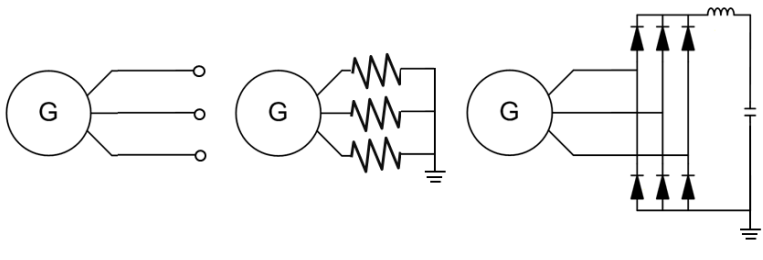
(a) 개방회로
(b) 저항회로
(c) 정류회로

그림 8 3D FEA에 연계된 외부회로

Fig. 8 External circuits considered in 3D FEA

\subsection{2 개방회로와 저항회로 검토 결과}

해석 모델이 2000rpm의 속도로 회전할 때, 개방회로에 대 한 해석결과와 저항회로에 대한 해석결과를 정리한 것이 표 3 과 같다. 저항회로는 $5 \mathrm{Ohm}$ 의 저항 3 개를 $\mathrm{Y}$ 결선으로 연 결하여 각 발전기 단자에 연결하여 구성하였다. 전류가 흐 르는 유무에 따라 유기기전력과 철손에서는 큰 차이가 없 다. 발전기 출력은 발전기 내부 손실을 제외하고, 순수하게 부하에 인가되는 출력이다.

\subsection{3 정류회로 검토 결과}

개방회로와 저항회로에서와 마찬가지로 정류회로에 대해 서도 해석모델이 2000rpm의 속도로 회전할 때, 그림 6(a)의 $\mathrm{FEA}$ 모델과 그림 9의 회로를 연동하여 자계해석을 수행하 였다. 발전시스템의 부하인 배터리에 최종 연결되는 충전부 는 $\mathrm{FEA}$ 와 연동해서 해석을 하기에는 회로가 너무 복잡하 고, 충전부의 효율이 일반적으로 $95 \%$ 이상으로 높기 때문에 따로 회로를 추가하지 않고 저항단으로 구성하였다. 대신, 충전기를 설계하는 과정에서는 그림 10 과 같이 상용프로그 램인 PSIM을 이용한 회로해석을 수행하기 위하여 벅 컨버 터 (buck converter) 시뮬레이션 회로도를 구성하였다. 정류 회로를 연동한 $3 \mathrm{D} \mathrm{FEA}$ 해석결과 중 전압과 전류에 대한 그래프는 그림 11 과 같다. 무부하 역기전력의 해석치와 실 험치 역기전력 $\mathrm{THD}$ 가 $0.35 \%$ 이하인 것을 고려하면 정류회 로 연동 시 발전기단의 전압과 전류는 상당한 고조파가 함 유되어 있으나, 그림 9 의 정류기회로에서 $\mathrm{R}-\mathrm{L}-\mathrm{C}$ 필터를 거 친 후 충전부 단에서 본 전압과 전류는 리플이 없이 일정한 값을 가지는 것을 확인 할 수 있다.
표 4에서는 정류회로를 연동한 $3 \mathrm{D} \mathrm{FEA} \mathrm{결과와} \mathrm{최종} \mathrm{설}$ 계 결과를 요약 정리하였다. 발전시스템 설계 사양 결정시 에 표 1 에서 발전기 출력을 $57.8 \mathrm{~W}$, 정류기의 출력을 $51.5 \mathrm{~W}$ 로 가정한데 비해서, 정류회로를 연동한 $3 \mathrm{D} \mathrm{FEA} \mathrm{결과는} \mathrm{발}$ 전기 출력이 $66 \mathrm{~W}$ 일 때, 정류기 출력이 $51.9 \mathrm{~W}$ 인 것을 볼 때, 필터를 포함한 정류회로에서의 손실이 큰 것을 알 수 있 다. 시스템 전체 효율을 개선시키기 위해서 정류기-충전기 설계 시에, 손실을 가장 많이 발생시키는 $\mathrm{R}-\mathrm{L}$ 필터의 값을 가능한 한 낮아지게 하였다.

\section{표 3 발전기 속도 2000rpm일 때 개방회로와 저항회로} 해석 결과

Table 3 Analysis results with open and resistor circuits at a speed of 2000rpm in generator

\begin{tabular}{||c||c|c|c||}
\hline \hline 분류 & 단위 & 개방회로 & $\begin{array}{c}\text { 저항회로 } \\
\text { (5-Ohm-Y결선) }\end{array}$ \\
\cline { 2 - 4 } & $\mathrm{Vrms} / \mathrm{ph}$ & 10.9 & 10.7 \\
\hline 유기기전력 & $\mathrm{W}$ & 8.8 & 8.7 \\
\hline 철손 & $\mathrm{W}$ & - & 2.0 \\
\hline 동손 & $\mathrm{W}$ & - & 64.5 \\
\hline 발전기출력 & $\mathrm{Vrms} / \mathrm{ph}$ & 10.9 & 10.4 \\
\hline 단자전압 & $\mathrm{Arms}$ & - & 2.1 \\
\hline 부하전류 & $\%$ & - & 85.8 \\
\hline 효율 & $\%$ & \multicolumn{1}{|l}{} \\
\hline \hline
\end{tabular}

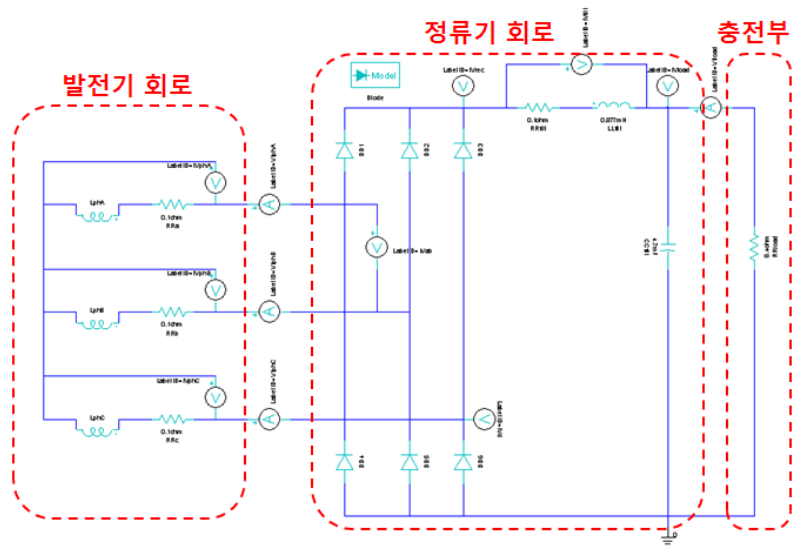

그림 $93 \mathrm{D} \mathrm{FEA}$ 를 위한 발전기 회로와 정류기 회로

Fig. 9 Generator and rectifier circuits for 3D FEA

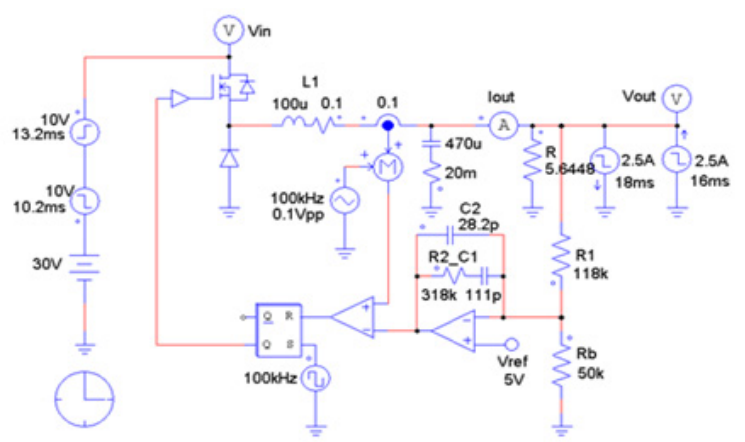

그림 $10 \mathrm{PSIM}$ 을 이용한 충전부 시뮬레이션 회로도

Fig. 10 Simulation circuit for charging part 


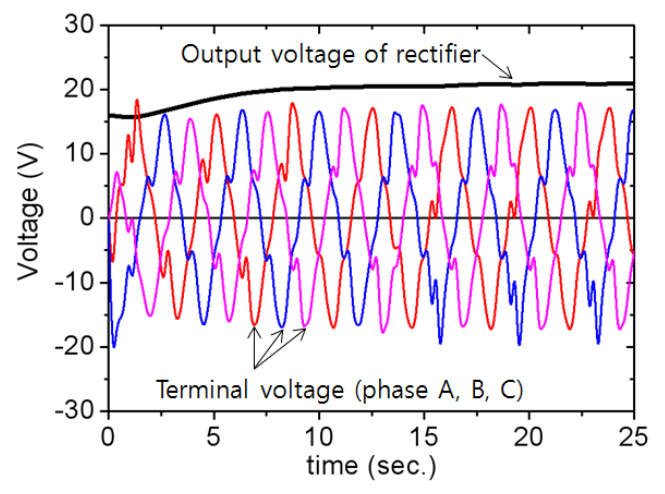

(a) 전압 파형

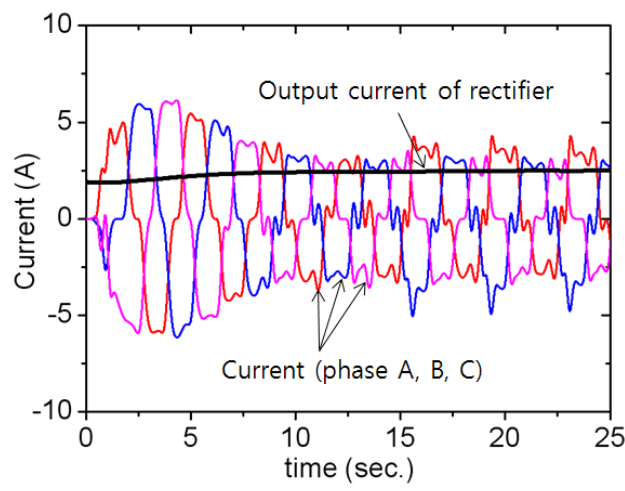

(b) 전류 파형

그림 11 정류회로를 연동한 3D FEA 해석결과

Fig. 11 3D FEA results considering rectifier circuit

표 4 발전기 설계 및 특성해석 결과

Table 4 Design and analysis results for generator

\begin{tabular}{|c|c|c|}
\hline 분류 & 단위 & 내용 \\
\hline \multirow{3}{*}{ 고정자 } & 코일 & 0.85mm 16turn/coil \\
\hline & 코어 & $\begin{array}{l}\mathrm{SMC}-\text { somaloy } 700-1 \mathrm{P}\left(\mathrm{TRS}^{*}=40 \mathrm{MPa} \text {, }\right. \\
\text { 포화자속밀도=1.56T @ } 10 \mathrm{kA} / \mathrm{m} \\
\text { 철손=44 W/kg@1T,400Hz,5X5mm²) }\end{array}$ \\
\hline & 치수 & 직경:81mm, 높이:15mm \\
\hline \multirow{3}{*}{ 회전자 } & 영구자석 & $\begin{array}{c}\text { 38SH }(\mathrm{Br}=1.23 \mathrm{~T}, \mathrm{bHc}>899 \\
\left.\mathrm{kA} / \mathrm{m} \text {,Working Temp. }=150^{\circ} \mathrm{C}\right)\end{array}$ \\
\hline & 코어 & SMC-somaloy700-1P \\
\hline & 치수 & 직경: $81 \mathrm{~mm}$, 높이:4.9mm \\
\hline \multirow{6}{*}{$\begin{array}{l}\text { 출력 } \\
\text { 특성 }\end{array}$} & 상저항 & $0.15 \mathrm{Ohm}$ (상온) \\
\hline & 전압 & $\begin{array}{c}\text { 유기기전력=11.24 Vrms/상, 정류회로 } \\
\text { 출력단 전압 }=20.9 \mathrm{~V}\end{array}$ \\
\hline & 전류 & $\begin{array}{c}\text { 상전류 }=2.7 \mathrm{Arms}, \text { 정류회로 출력단 } \\
\text { 전류 }=2.5 \mathrm{~A}\end{array}$ \\
\hline & 출력 & $\begin{array}{l}\text { 발전기 출력단 }=66.0 \mathrm{~W}, \\
\text { 정류커패시터 }=51.9 \mathrm{~W}\end{array}$ \\
\hline & 손실 & 동손 $=3.5 \mathrm{~W}$, 철손 $=9.1 \mathrm{~W}$ \\
\hline & 효율 & $84.1 \%$ \\
\hline
\end{tabular}

* TRS : SMC 시편의 강도를 나타내는 척도, 일반 규소강판 의 $\mathrm{TRS}=400^{\sim} 500 \mathrm{MPa}$

\section{3 자가 발전 시스템의 실험결과}

그림 12 는 자가 발전 시스템 성능 테스트를 위해 구성한 다이나모와 발전 시스템이다. 실험을 위해서 발전시스템은 기어부와 발전기를 하나의 모듈로, 또 정류기와 충전기를 또 다른 모듈로 구분해서 제작하였다. 그리고 해석에서와 마찬 가지로 발전기 단이 개방회로인 경우와 저항회로가 붙었을 때, 그리고 정류기와 충전기가 붙었을 때 각각에 대해서 실 험을 수행하였다. 표 5는 해석결과와 실험결과를 비교한 것 이다. 상저항은 계산값과 측정값이 잘 일치하고 있으므로 권선이 사양대로 제작되었음을 유추할 수 있다. 그러나 유 기기전력 측정값이 계산값보다 낮은 값을 가지는 것은 제작 된 발전기의 자기 소스인 영구자석의 특성이 차이가 나던지 자기회로의 자기저항이 설계 때 보다 증가한 것으로 유추되 었다. 실제 제작된 발전기에서 영구자석의 표면자속밀도 오 차는 $3 \%$ 미만인데 비해, 코어치수를 검토했을 때 성형된 $\mathrm{SMC}$ 코어 치수의 불균일로 인해 설계 시 고려한 공극 $0.5 \mathrm{~mm}$ 보다 평균 $0.1 \mathrm{~mm}$ 정도 증가한 것을 확인하였다. 개 방회로 상태에서 유기기전력의 오차는 저항회로와 정류회로 에서 출력오차로 나타났는데, 특히 정류-충전 회로에서는 발전기 속도 $2000 \mathrm{rpm}$ 일 때 실험에서 충전이 되지 않아 속 도를 $2200 \mathrm{rpm}$, 즉 수동입력으로 환산 시 $110 \mathrm{rpm}$ 일 때, 그 림 13 과 같이 $48 \mathrm{~W}$ 로 충전이 진행되는 것을 확인하였다. 공 극 증가로 인해 출력이 설계 시 계산한 값보다 낮게 나왔지 만, 손실 또한 낮아져 효율은 오히려 증가하였다.

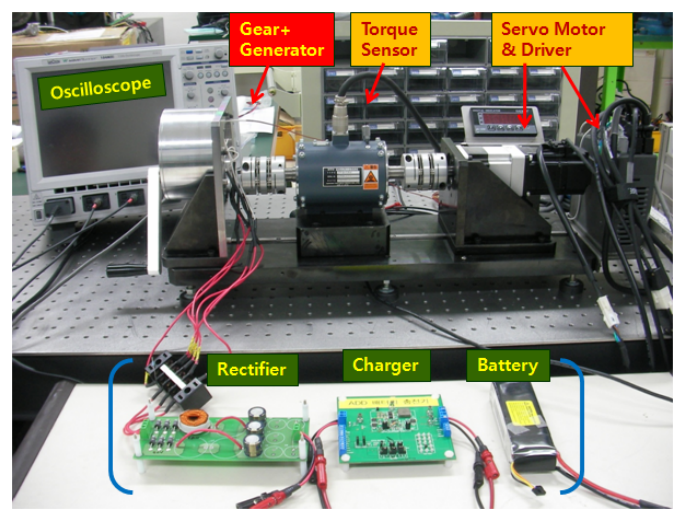

그림 12 발전기 시스템 시험 구성도

Fig. 12 Test system for generating system

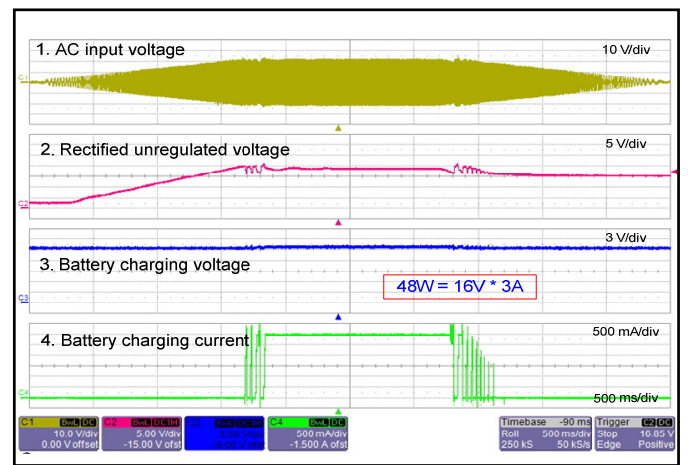

그림 13 서보모터 입력에 대한 충전파형

Fig. 13 Charging waveform by servo motor input 
표

5 발전기 2000rpm (수동 100rpm) 구동에서 발전시스 템 실험결과와 계산값 비교

Table 5 Comparison of testing and calculating results at a speed of 2000rpm in generator

\begin{tabular}{||c||c||c|c||}
\hline \hline 분류 & 단위 & 계산값 & 측정값 \\
\hline \hline 상저항(개방회로) & Ohm & 0.15 & 0.15 \\
\hline 유기기전력(개방회로) & Vrms & 10.9 & 9.6 \\
\hline 상전류(저항회로) & $\mathrm{Arms}$ & 2.1 & 1.8 \\
\hline 출력(저항회로) & $\mathrm{W}$ & 64.5 & 50.2 \\
\hline 출력(정류회로) & $\mathrm{W}$ & 52 & $\begin{array}{c}48 \\
(110 \mathrm{rpm})\end{array}$ \\
\hline 효율(저항회로) & $\%$ & 86 & 88 \\
\hline
\end{tabular}

\section{3. 결 론}

본 논문에서는 자가 발전 시스템을 연구하는 과정에서 특 히 발전기를 중심으로 설계, 해석, 실험하는 과정을 보였다. 회전자와 고정자 결합 시 치수 오차로 인해 계산값과 측정 값에서 다소 큰 오차가 발생하였지만, 설계 사양에서 가정한 수동입력 $85 \mathrm{rpm}^{\sim} 110 \mathrm{rpm}$ 사이에서 $50 \mathrm{~W}$ 급 배터리 충전이 가 능한 것을 서보모터 입력에 의한 실험으로 확인하였을 뿐만 아니라, 그림 14에서 보는 바와 같이 일정한 속도를 유지하 지 못해서 발전기와 정류기단의 전압파형이 많이 흔들림에 도 불구하고 사람이 직접 입력하는 수동 입력에 의해서도 $50 \mathrm{~W}$ 급 배터리가 충전이 되는 것을 확인하였다. 그리고 시 험후 발전시스템을 결합해서 제작한 하나의 발전시스템은 그림 15 에서 보이고 있는데, 무게가 설계 사양에서 예측한 것보다 훨씬 개선된 $1.68 \mathrm{~kg}$ 이 되었다. 본 논문이 다양한 용 량의 소형 발전기를 설계하는데 도움이 되기를 바란다.

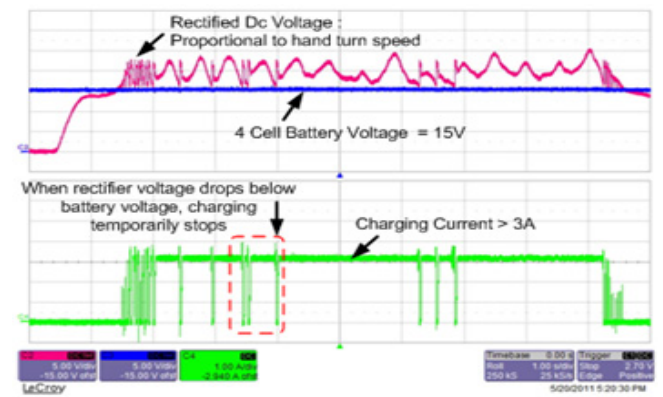

그림 14 수동 입력에 대한 충전파형

Fig. 14 Charging waveform by manual input

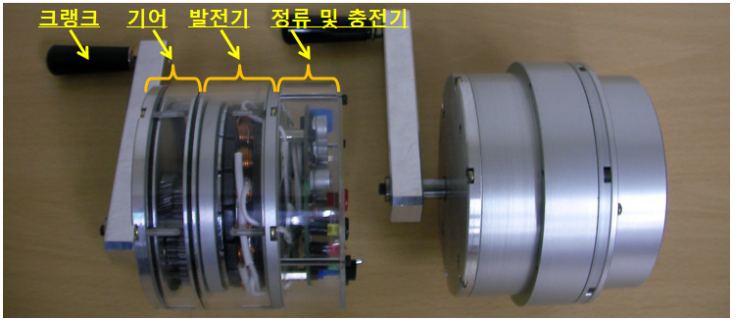

그림 15 자가 발전 시스템 시작기 $(1.68 \mathrm{~kg})$

Fig. 15 Prototype of a manual generator system

\section{감사의 글}

본 연구는 방위사업청 및 국방과학연구소 지원으로 수행되는 차세대군용전원특화연구센터 사업의 일환으 로 수행되었습니다.

\section{참 고 문 헌}

[1] 고정호, 박용운, “지상 무인전투체계 기술발전 방향”, 국방과학기술 플러스, vol.43, pp.1-12, 2007.

[2] 이광일, 류영진, 이치호, “통신전자전 무기체계 및 기술 현황”, 국방과학기술플러스, vol.58, pp.1-12, 2008.

[3] 이지영, 문승렬, 구대현, 방덕제, 폴린더, "휴대형 수동 발전 시스템용 발전기 설계”, 대한전기학회 하계학술대 회 논문집, 2010.

[4] W.L.Moyers, H.S. Coombe, and A.Hartman, "Harvesting Energy with Hand-Crank Generators to Support Dismounted Soldier Missions," available at http://www.dtic.mil/dtic/.

[5] 이지영, 문승렬, 구대현, 방덕제, 폴린더, “축방향 자속 전기기기를 이용한 휴대용 발전기 개발”, 한국군사과학 기술학회 2010년도 종합학술대회

[6] 문승렬, 이지영, 구대현, “휴대용 수동 발전기용 리튬 베너리 충전기 개발”, 한국군사과학기술학회 2010년도 종합학술대회

[7] A.J. Jansen and A.L.N. Stevels, "Human power, a sustainable option for electronics," Proceedings of the 1999 IEEE international symposium on Electronics and the Environment, pp.215-218, 1999.

[8] A. Jansen and P. Slob, "Human power: comfortable one-hand cranking," International conference on engineering design (ICED), August 2003.

저 자 소 개

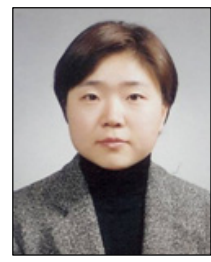

\section{이 지 영 (李 旨 榮)}

1977년 5월 26일 생. 2000년 창원대학교 공과대학 전기공학과 졸업. 2002년 동 대 학원 전기공학과 졸업(석사), 2006년 동 대학원 전기공학과 졸업(박사). 2006 현 재 한국전기연구원 전기추진연구본부 전 동력연구센터 선임연구원.

Tel : 055-280-1416

Fax : 055-280-1490

E-mail : jylee@keri.re.kr 


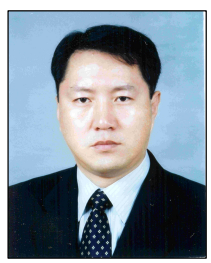

\section{구 대 현 (具 大 鉉)}

1963년 9월 21일 생. 1989년 한양대학교 공과대학 전기공학과 졸업. 1991년 동 대 학원 전기공학과 졸업(석사), 2002년 동 아대학교 전기공학과 졸업(박사). 1991 현재 한국전기연구원 전기추진연구본부 전동력연구센터 센터장 (책임연구원).

Tel : 055-280-1486

Fax : 055-280-1490

E-mail : dhk371@keri.re.kr

\section{한 충 규 (韓 忠 奎)}

1970년 생. 1993년 연세대학교 물리학과 졸업. 1996년 동 대학원 물리학과 졸업 (석사), 2011 현재 동 대학원 물리학과 재학중(박사과정). 1996 1998 현대전자산 업, 1998 현재 국방과학연구소 4 본부 2 부 선임연구원.

Tel : 042-821-4169

E-mail : ckhan@add.re.kr 